\title{
DETERMINATION OF CANDESARTAN, HYDROCHLOROTHIAZIDE AND ROSUVASTATIN AS ACTIVE INGREDIENTS OF A POLYTABLET BY A CHROMATOGRAPHIC-DENSITOMETRIC METHOD
}

\author{
MARIUSZ STOLARCZYK*, ANNA MAŚLANKA, ANNA APOLA, ANNA KWIECIEŃ \\ and URSZULA HUBICKA
}

Department of Inorganic and Analytical Chemistry

Jagiellonian University Medical College, Faculty of Pharmacy

9 Medyczna St., 30-688 Krakow, Poland

\begin{abstract}
The TLC method with densitometric detection was used to identify and determine the content of candesartan (CAN), hydrochlorothiazide (HCT), and rosuvastatin (ROS) as active ingredients of a potential FDC (fixed-dose combination) preparations. $\operatorname{TLC~}_{254}$ plates were used as a stationary phase and a mobile phase was composed of: hexane - ethyl acetate - methanol - water $-99.5 \%$ acetic acid $(8.4: 8: 3: 0.4: 0.2 \mathrm{~V} / \mathrm{V})$. The obtained chromatograms are characterized by a good separation of the tested substances, enabling the assessment of results in both qualitative and quantitative aspects. The process of method validation has shown that the method is specific for the analyte and is characterized by high sensitivity. The linearity was determined in a wide range, from 0.048 to $1.824 \mathrm{mg} / \mathrm{spot}$ for CAN, from 0.058 to $1.102 \mathrm{mg} / \mathrm{spot}$ for HCT and from 0.032 to $1.216 \mathrm{mg}$ /spot for ROS and determination coefficient $\left(\mathrm{R}^{2}\right)$ was between $0.9985-0.9990$ depending on the substance being determined. The recovery ranged from $96.8 \%$ to $101.12 \%$. The precision of the method was satisfactory, RSD values were in the range from $0.43 \%$ to $2.12 \%$.
\end{abstract}

Keywords: FDC, TLC, candesartan, hydrochlorothiazide, rosuvastatin, determination

Acronyms/abbreviations: - CAN - candesartan, HCT - hydrochlorothiazide, ROS - rosuvastatin, TLC - Thinlayer chromatography, FDC - fixed-dose combination, ICH - International Conference on Harmonisation

The growing presence of cardiovascular diseases coexisting with other diseases in the population, and the increasing number of deaths associated with it causes that so-called fixed-dose combination (FDC) preparations are being developed to be used in polytherapy.

In recent years, a number of studies have been conducted to assess the effectiveness of this type of combination in therapy and to prevent incidents associated with cardiovascular diseases. Many studies of this type also included studies aiming at the evaluation of the effectiveness of the concomitant use of rosuvastatin, candesartan, and hydrochlorothiazide in patients with specific cardiovascular disorders (1). The chemical structures of the tested substances are shown in Figure 1.

Candesartan (CAN) - 2-Ethoxy-1-\{[2'- $(1 \mathrm{H}-$ tetrazol-5-yl)-4-biphenylyl]methyl $\}-1 \mathrm{H}$-benzimidazole-7-carboxylic acid (Fig. 1A) is a selective AT1 receptor antagonist for angiotensin II. Blocking these receptors leads to a lowering of blood pressure, which is why these drugs are used to treat hypertension.

Rosuvastatin (ROS) - (3R,5S,6E)-7-\{4-(4Fluorophenyl)-6-isopropyl-2-[methyl (methylsulfonyl)amino]-5-pyrimidinyl \}-3,5-dihydroxy-6-heptenoic acid (Fig. 1B) belongs to the group of drugs blocking the enzyme 3-hydroxy-3-methylglutaryl coenzyme A reductase (HMG-CoA reductase), which is crucial for cholesterol synthesis. As a result, both LDL and total cholesterol are lowered. In addition to lowering cholesterol, statins have pleiotropic effects such as regulation of nitric oxide synthesis leading to vasodilatation and show an antioxidant effect.

Hydrochlorothiazide (HCT) - 6-chloro-1,1dioxo-3,4-dihydro-2H-1,2,4-benzothiadiazine-7sulfonamide (Fig. 1C) is a drug with diuretic and

* Corresponding author: e-mail: mariusz.stolarczyk@uj.edu.pl 
hypotensive effect from the thiazide group. It works by inhibiting the reverse transport of sodium ions. In this way, it increases the excretion of sodium and water from the body. Its special significance results from the long duration of action and is used in the long-term treatment of hypertonia and chronic heart failure. In addition, hydrochlorothiazide has been used in the treatment of acute and chronic edema.

A number of methods have been described in the literature that can be used to quantify the compounds mentioned. The most commonly used methods are separation methods. The results of simultaneous determination of CAN and HCT using the HPLC method are presented, among others, in papers (2-5), by TLC method in papers (6-8).

In addition to separation methods, a spectrophotometric method using curves derived from absorption spectra was successfully used to determine active substances in two-component mixtures (10-12). ROS was also determined using separation methods such as HPLC (13-15), TLC $(16,17)$, spectrophotometric method $(18,19)$, and electroanalytical methods(20-24).

The results of studies aiming at the evaluation of the effectiveness of simultaneous use of the above-mentioned drugs indicate a beneficial effect of polytherapy (rosuvastatin $10 \mathrm{mg}$ daily, candesartan $16 \mathrm{mg}$ daily, and hydrochlorothiazide $12.5 \mathrm{mg}$ daily), which is associated with a significantly lower rate of cardiovascular events than in the placebo group (25). Possible interactions between rosuvastatin and candesartan and their tolerance by patients were also investigated. The results confirmed that the pharmacokinetic properties met the criteria for bioequivalence. It was found that the FDC preparations were safe, well-tolerated and no significant differences in the assessment of treatment safety were observed (26). Therefore, the authors decided to develop a method for the simultaneous determination of candesartan, hydrochlorothiazide, and rosuvastatin as active ingredients of a potential FDC (fixed-dose combination) preparations using thinlayer chromatography with densitometric detection.

\section{EXPERIMENTAL}

\section{Instruments and materials}

TLC system consists of Camag Linomat autosampler (Sonnenmattstrasse 11, CH-4132 Muttenz, Switzerland), Camag microsyringe (100 $\mu L$ ), and Camag TLC scanner 35/N/30319 with winCATS software. A short wavelength UV lamp emitting at $254 \mathrm{~nm}$ and $366 \mathrm{~nm}$ was also used (Desaga, Wiesloch, Germany). Aluminum-backed TLC silica gel $60 \mathrm{~F}_{254}$ plates $(20 \times 20 \mathrm{~cm})$ with 0.25 $\mathrm{mm}$ thickness were obtained from E. Merck, Darmstadt, Germany.

\section{Chemicals}

Reference standards: candesartan (CAN) 2-ethoxy-1-(\{4-[2-(2H-1,2,3,4-tetrazol-5-yl)phenyl]phenyl \}methyl)-1H-1,3-benzodiazole-7-carboxylic acid, CAS Number: 145040-37-5, hydrochlorothiazide (HCT) - 6-chloro-1,1-dioxo3,4-dihydro-2H-1,2,4-benzothiadiazine-7-sulfonamide, CAS Number: 58-93-5, rosuvastatin (ROS) (3R,5S,6E)-7-[4-(4-Fluorophenyl)-2-(N-methylmethanesulfonamido)-6-(propan-2-yl)pyrimidin-5yl]-3,5 dihydroxyhept-6-enoic acid, CAS Number: 147098-20-2, were supplied by Sigma-Aldrich (Germany). Hexane, ethyl acetate, methanol, 95.5\% acetic acid were purchased from Merck (Germany).<smiles>CCOc1nc2cccc(C(=O)O)c2n1Cc1ccc(-c2ccccc2-c2nnn[nH]2)cc1</smiles><smiles>CC(C)c1nc(N(C)S(C)(=O)=O)nc(-c2ccc(F)cc2)c1/C=C/C(O)CC(O)CC(=O)O</smiles><smiles>NS(=O)(=O)c1cc2c(cc1Cl)NCNS2(=O)=O</smiles>

Figure 1. Chemical structure of candesartan (A), rosuvastatin (B), and hydrochlorothiazide(C). 
All reagents and solvents used were of analytical reagent grade.

\section{Pharmaceutical preparations}

Two pharmaceutical preparations were used for the determinations: Carzap ${ }^{\circledR} \mathrm{HCT} 16 \mathrm{mg}+12.5 \mathrm{mg}$ manufactured by Zentiva, Prague, Czech Republic, series No. 1608A045, one tablet contains $16 \mathrm{mg}$ of candesartan cilexetil and $12.5 \mathrm{mg}$ hydrochlorothiazide; Suvardio $10 \mathrm{mg}$ manufactured by Sandoz GmbH, Kundl, Austria, series No. GB1246 one tablet contains $10 \mathrm{mg}$ of rosuvastatin calcium.

\section{Standard solutions}

The standard solutions were prepared by weighing the appropriate mass of the standard substance on an analytical balance, transferring it quantitatively into a $10 \mathrm{~mL}$ volumetric flask, and making it up to the given volume with methanol. By following this procedure for all tested substances, clear solutions were obtained at the following concentrations: CAN: $0.960 \mathrm{mg} / \mathrm{mL}$ and $0.048 \mathrm{mg} / \mathrm{mL}, \mathrm{HCT}$ : $0.760 \mathrm{mg} / \mathrm{mL}$ and $0.058 \mathrm{mg} / \mathrm{mL}$, ROS: 0.640 $\mathrm{mg} / \mathrm{mL}$ and $0.032 \mathrm{mg} / \mathrm{mL}$.

\section{Model mixture}

10 tablets of Carzap ${ }^{\circledR} \mathrm{HCT}$ and 10 tablets of Suvardio were powdered. From the powdered tablet mass, sample weights corresponding to the average tablet weight of the tested preparations were made and mixed. The model mixture was extracted with $5 \mathrm{~mL}$ of methanol by placing the extract in an ultrasonic bath for $15 \mathrm{~min}$. The solution was filtered through EMD Millipore Syringe Filters $0.45 \mu \mathrm{m}$. The mixture was diluted four times before the determination. The prepared solution containing CAN: 41.6\%, HCT: $32.5 \%$, ROS: $26.0 \%$ corresponded in terms of composition and content to the mixture used in polytherapy in clinical studies conducted and described by Yusuf et al (25).

\section{Mobile phase:}

Hexane - ethyl acetate - methanol - water $95.5 \%$ acetic acid $(8.4: 8: 3: 0.4: 0.2 \mathrm{~V} / \mathrm{V})$

\section{Chromatographic conditions}

In order to determine the separation conditions of analyzed components, $2 \mu \mathrm{l}$ of appropriate standard solutions of CAN at a concentration of 0.960 $\mathrm{mg} / \mathrm{mL}, \mathrm{HCT}$ at a concentration of $0.760 \mathrm{mg} / \mathrm{mL}$, ROS at a concentration of $0.640 \mathrm{mg} / \mathrm{mL}$, and the model mixture solution were applied in the form of $8 \mathrm{~mm}$ bands to the chromatographic plates measur- ing $10 \times 10 \mathrm{~cm}$ with silica gel $\mathrm{G} \mathrm{F}_{254}$. Chromatograms were developed using a mobile phase composed of: hexane - ethyl acetate - methanol - water $-95.5 \%$ acetic acid $(8.4: 8: 3: 0.4: 0.2 \mathrm{~V} / \mathrm{V})$. The chromatogram was developed to a height of $95 \mathrm{~mm}$ in a chromatographic chamber saturated with the mobile phase for $15 \mathrm{~min}$. After development, the chromatograms were dried at room temperature and subjected to visual analysis illuminating the chromatographic plate with monochromatic light at a wavelength of $\mathrm{l}=254 \mathrm{~nm}$, and then the densitometric measurements were also performed.

\section{METHOD VALIDATION}

The method was validated according to the ICH recommendations (27) and Polish Pharmacopoeia, XIth edition (28).

\section{Specificity}

Specificity was checked by comparing the retention factor $\left(R_{F}\right)$ for the peaks of the standard solutions and model mixture. The resolution of the registered peaks was calculated (a - separation factor, Rs - resolution factor).

\section{Accuracy}

The accuracy of the method was determined by providing the percentage of recovery $(\% \mathrm{R})$ of the tested components. For this purpose, standard substances in amounts from $80 \%$ to $120 \%$ of the determined content were added to the model mixture. The analysis was carried out before and after the addition of standard substances. The recovery percentage was calculated according to the formula: $\mathrm{R}=\mathrm{A} / \mathrm{B} \times 100 \%$, where: $\mathrm{A}$ - the determined amount of tested substance, B - the known amount of tested substance. Five repetitions were performed for each level.

\section{Precision}

Compliance of the determination results was checked on standard solutions prepared by dissolving the ingredients in methanol, taking into account the proportions in which they most often occur in polytherapy. Five determinations were carried out at three concentration levels: $50 \%, 100 \%$, and $150 \%$ of the determined content.

\section{Linearity}

Linearity was defined as the relationship between peak areas ( $p)$ and concentration ( $\mu \mathrm{g} / \mathrm{spot})$, using solutions at the following concentrations: CAN $0.048 \mathrm{mg} / \mathrm{spot}$, HCT $0.058 \mathrm{mg} / \mathrm{spot}$, ROS $0.032 \mathrm{mg} / \mathrm{spot}$. Two measurements were made for 
each component for concentrations respectively: $0.048,0.240,0.432,0.672,0.864,1.056,1.248$, $1.440,1.632,1.824 \mathrm{mg} / \mathrm{spot}$ for CAN, from 0.058 , $0.174,0.290,0.406,0522,0.638,0.754,0.870$, $0.986,1.000,1.102 \mathrm{mg} / \mathrm{spot}$ for HCT and from $0.032,0.160,0.288,0.448,0.576,0.704,0.832$, $0.960,1.088,1.216 \mathrm{mg} / \mathrm{spot}$ for ROS.
Limit of detection (LOD) and limit of quantification (LOQ)

The limit of detection and quantification was determined from the linearity in the concentration ranges: from 0.048 to $0.0864 \mathrm{mg} / \mathrm{spot}$ for CAN, from 0.058 to $0.522 \mathrm{mg} / \mathrm{spot}$ for HCT and from 0.032 to $0.832 \mathrm{mg} / \mathrm{spot}$ for ROS. The following formulas

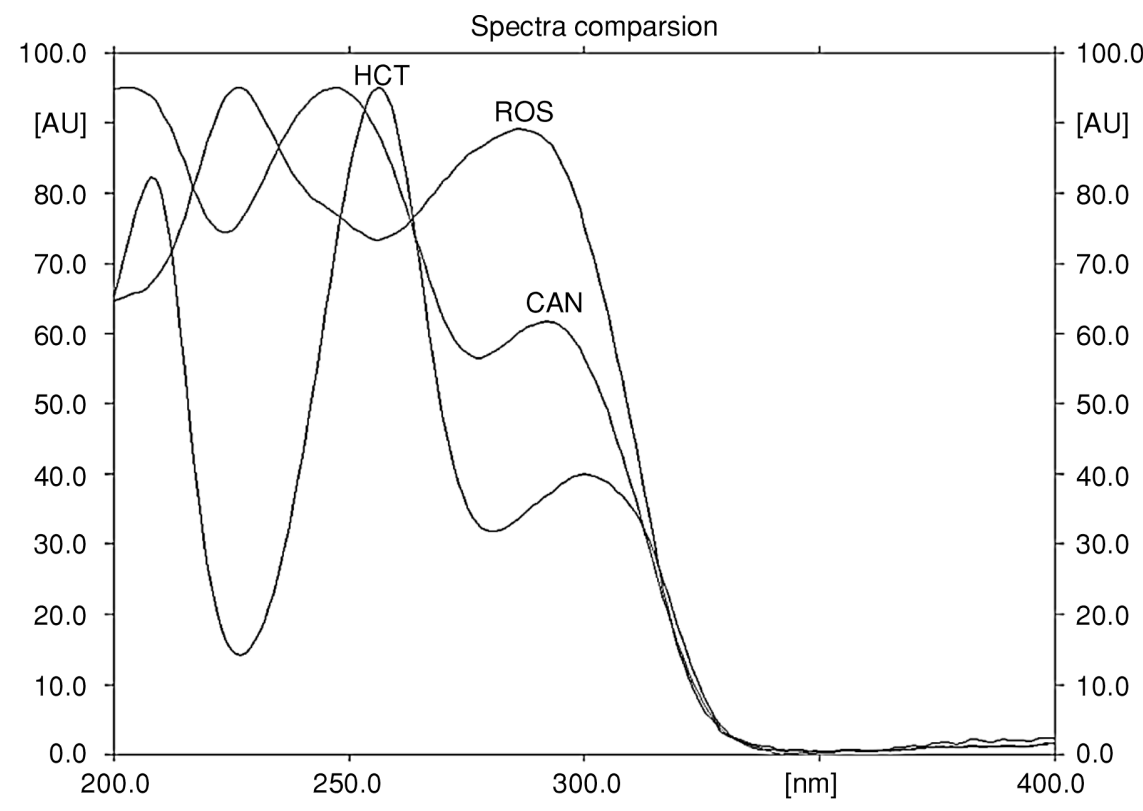

Figure 2. Spectra of CAN, HCT, and ROS recorded directly from a chromatogram.

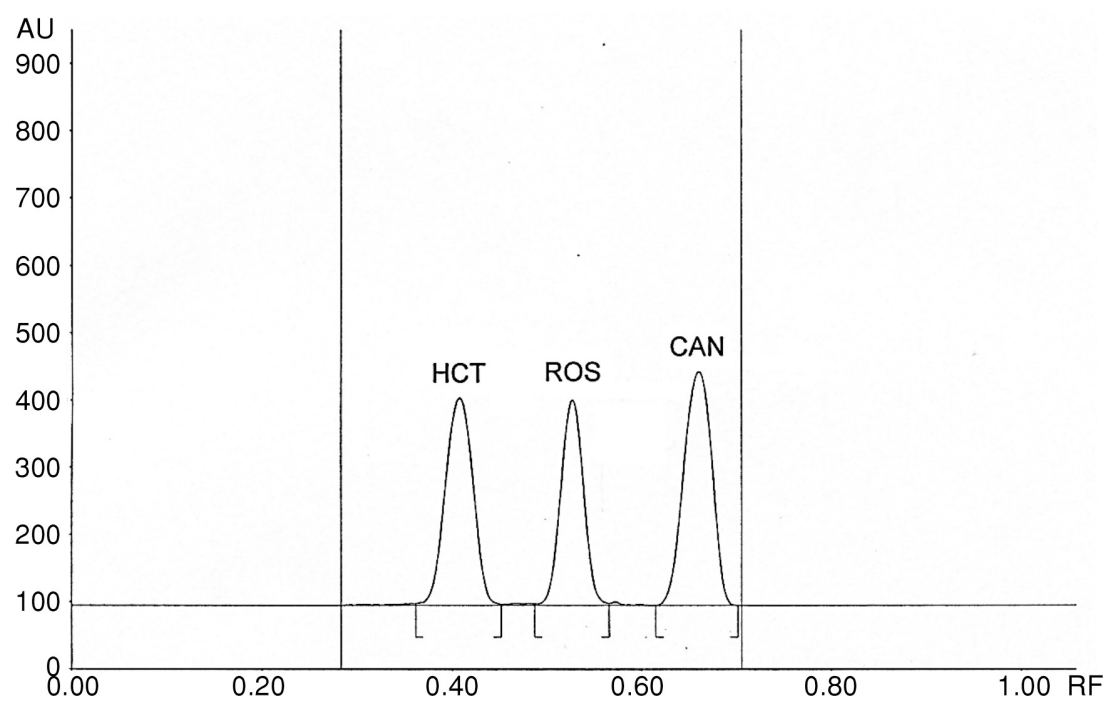

Figure 3. Two-dimentional TLC densitogram of CAN $(c=3.2 \mathrm{mg} / \mathrm{mL}), \mathrm{HCT}(\mathrm{c}=2.5 \mathrm{mg} / \mathrm{mL})$ and ROS $(\mathrm{c}=2.0 \mathrm{mg} / \mathrm{mL})$. 
were used in the calculations: $\mathrm{LOD}=3.3 \times \mathrm{S}_{\mathrm{y}} / \mathrm{A}$, $\mathrm{LOQ}=10 \times \mathrm{S}_{\mathrm{y}} / \mathrm{A}$, in which: Sy - standard error of the estimate, $\mathrm{a}-$ the slope of the straight line.

\section{Robustness}

The robustness of the method was verified by analyzing the influence of slight changes in the system on the obtained results. The following parameters were changed: chromatographic chamber saturation time $\pm 10 \mathrm{~min}$, the volume of the mobile phase $\pm 5 \%$, type of the stationary phase (HPTLC $60 \mathrm{~F}_{254}$ ), type of the chromatographic chamber used. None of these changes influenced the obtained results, which may prove that the method is resistant.
Determination of components in the model mixture

The usefulness of the method was assessed by determining the content of tested substances in mixtures resulting from the appropriate solutions prepared from pharmaceutical preparations. $2 \mu \mathrm{L}$ of standard solutions and the model mixture were applied to TLC plates. Developed and dried chromatograms were subjected to densitometric measurements at the previously given wavelengths. Identification of the determined components was made by comparing the values of $\mathrm{R}_{\mathrm{F}}$ coefficients and absorption spectra for the tested model mixtures and standard solutions. To calculate the content of active

Table 1. Validation of the developed method with the statistical evaluation.

\begin{tabular}{|c|c|c|c|}
\hline & CAN & HCT & ROS \\
\hline $\mathrm{R}_{\mathrm{F}}$ & $\sim 0.66$ & $\sim 0.41$ & $\sim 0.53$ \\
\hline Linearity range $(\mu \mathrm{g} / \mathrm{spot})$ & $0.048-1.824$ & $0.058-1.102$ & $0.032-1.216$ \\
\hline $\begin{array}{c}\text { LOD }(\mu \mathrm{g} / \mathrm{spot}) \\
\mathrm{a} \\
\mathrm{S}_{\mathrm{y}} \\
\end{array}$ & $\begin{array}{c}0.056 \\
5828.7 \\
98.6 \\
\end{array}$ & $\begin{array}{c}0.043 \\
6992.3 \\
91.3 \\
\end{array}$ & $\begin{array}{c}0.049 \\
5051.0 \\
75.8 \\
\end{array}$ \\
\hline $\begin{array}{c}\text { LOQ }(\mu \mathrm{g} / \mathrm{spot}) \\
\text { Precision } 50 \%[\mathrm{mg} / \mathrm{mL}] \\
\bar{X} \\
\text { SD } \\
\text { RSD }\end{array}$ & $\begin{array}{c}0.169 \\
\\
0.558 \\
0.0094 \\
1.7\end{array}$ & $\begin{array}{c}0.130 \\
\\
0.254 \\
0.0050 \\
1.9\end{array}$ & $\begin{array}{c}0.150 \\
\\
0.316 \\
0.0048 \\
1.6\end{array}$ \\
\hline $\begin{array}{c}\text { Precision } 100 \%(\mathrm{mg} / \mathrm{mL}) \\
\overline{\mathrm{X}} \\
\text { SD } \\
\text { RSD }\end{array}$ & $\begin{array}{c}0.971 \\
0.0088 \\
0.9\end{array}$ & $\begin{array}{c}0.495 \\
0.0105 \\
2.1\end{array}$ & $\begin{array}{c}0.612 \\
0.0058 \\
0.9\end{array}$ \\
\hline $\begin{array}{c}\text { Precision } 150 \%(\mathrm{mg} / \mathrm{mL}) \\
\overline{\mathrm{X}} \\
\text { SD } \\
\text { RSD }\end{array}$ & $\begin{array}{c}1.584 \\
0.0270 \\
1.7\end{array}$ & $\begin{array}{c}0.757 \\
0.0033 \\
0.4\end{array}$ & $\begin{array}{c}0.913 \\
0.0067 \\
0.7\end{array}$ \\
\hline $\begin{array}{c}\text { Recovery } 80 \%(\%) \\
\bar{X} \\
\text { SD } \\
\text { RSD }\end{array}$ & $\begin{array}{c}96.80 \\
0.367 \\
0.4\end{array}$ & $\begin{array}{c}98.08 \\
1.226 \\
1.2\end{array}$ & $\begin{array}{c}100.79 \\
0.808 \\
0.8\end{array}$ \\
\hline $\begin{array}{c}\text { Recovery } 100 \%(\%) \\
\overline{\mathrm{X}} \\
\text { SD } \\
\text { RSD }\end{array}$ & $\begin{array}{c}100.75 \\
1.280 \\
1.3\end{array}$ & $\begin{array}{c}101.12 \\
1.798 \\
1.8\end{array}$ & $\begin{array}{c}97.88 \\
0.559 \\
0.6\end{array}$ \\
\hline $\begin{array}{c}\text { Recovery } 120 \%(\%) \\
\bar{X} \\
\text { SD } \\
\text { RSD }\end{array}$ & $\begin{array}{c}98.44 \\
0.723 \\
0.7\end{array}$ & $\begin{array}{c}97.54 \\
0.747 \\
0.8\end{array}$ & $\begin{array}{c}98.94 \\
0.706 \\
0.7\end{array}$ \\
\hline $\mathrm{R}_{\mathrm{s}}$ & \multicolumn{2}{|c|}{$\begin{array}{c}\text { HCT : ROS } \\
1.80\end{array}$} & $\begin{array}{c}\text { ROS : CAN } \\
2.50\end{array}$ \\
\hline$\alpha$ & \multicolumn{2}{|c|}{$\begin{array}{c}\text { HCT : ROS } \\
1.62\end{array}$} & $\begin{array}{c}\text { ROS : CAN } \\
1.82\end{array}$ \\
\hline
\end{tabular}

$\mathrm{RF}$ - retention factor, - mean value, SD - standard deviation, RSD - relative standard deviation, Rs - resolution factor, - separation factor. 


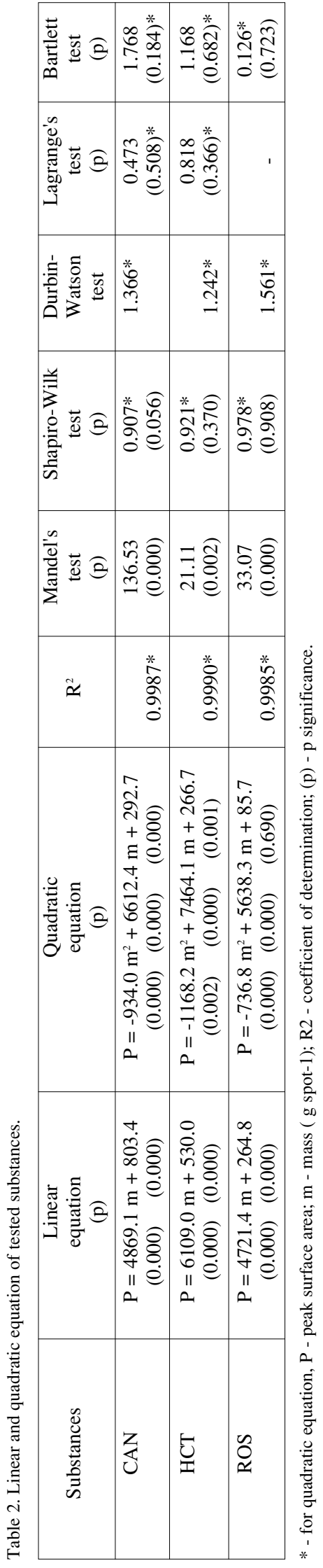

substances in the model mixture, the peak areas registered for the tested solutions and the corresponding standard solutions were compared.

\section{RESULTS AND DISCUSSION}

The development of the concept of polytablets and research on their application in the therapy and prevention of diseases related to the cardiovascular system, along with the development of technological methods to obtain an effective and safe form of the drug, leads to the need to search for new, simple, cheap, and effective methods of analysis of multicomponent drugs.

In accordance with the assumption adopted for the purpose of the work, a new chromatographic and densitometric procedure was developed, allowing for the simultaneous identification and quantification of active substances in a potential ternary polytablet composed of CAN, HCT, and ROS. After analyzing the absorption spectra of the tested drugs registered directly from the chromatograms in the range from 200 to $400 \mathrm{~nm}$ (Fig. 2), it was found that due to the overlap of absorption maxima for individual components, it is difficult to use the spectrophotometric method to determine these substances in a mixture (12). These interferences mean that the determination of the analytical wavelength for individual components in their mixture does not guarantee satisfactory quantitative results using spectrophotometric or spectrofluorimetric methods.

The selection of a suitable mobile phase was preceded by a literature review and was based on a series of tests that took into account the different qualitative and quantitative composition of solvents. The suitability of the chloroform: methanol: $95.5 \%$ acetic acid mixture $(9: 2: 0.1 \mathrm{~V} / \mathrm{V})$ was checked. The use of this phase gave poor resolution and an asymmetrical peak of CAN. In the chloroform: ethyl acetate: $95.5 \%$ acetic acid : water $(4: 4: 4: 1 \mathrm{~V} / \mathrm{V})$ mixture, proper separation of HCT and ROS peaks was not achieved, $R_{F}$ values were very close to each other, which did not guarantee adequate accuracy and precision of determinations. Only the use of a mixture composed of hexane : ethyl acetate : methanol : water : $95.5 \%$ acetic acid $(8.4: 8: 3: 0.4$ $: 0.2 \mathrm{~V} / \mathrm{V}$ ) and the use of TLC plates coated with silica gel 60 with the fluorescent agent $\mathrm{F}_{254}$ allowed to obtain well-shaped, separated and symmetrical peaks for all tested substances. Only peaks from the analyzed components appear on the recorded densitograms. $\mathrm{R}_{\mathrm{F}}$ values were comparable and were respectively $0.66 \pm 0.013$ for CAN, $0.41 \pm 0.009$ for HCT, and $0.53 \pm 0.015$ for ROS, which gives the 
Table 3. Determination results of active substances in a studied model mixture $(n=5)$.

\begin{tabular}{|c|c|c|c|}
\hline $\begin{array}{c}\text { Model } \\
\text { mixture }\end{array}$ & $\begin{array}{c}\text { CAN } \\
(\mathrm{mg} / \mathrm{mL})\end{array}$ & $\begin{array}{c}\text { HCT } \\
(\mathrm{mg} / \mathrm{mL})\end{array}$ & $\begin{array}{c}\text { ROS } \\
(\mathrm{mg} / \mathrm{mL})\end{array}$ \\
\hline \multirow{3}{*}{ Determined content } & $\begin{array}{c}\overline{\mathrm{X}}=0.808 \\
\mathrm{SD}=0.0161\end{array}$ & $\begin{array}{c}\overline{\mathrm{X}}=0.625 \\
\mathrm{SD}=0.0040\end{array}$ & $\begin{array}{c}\overline{\mathrm{X}}=0.517 \\
\mathrm{SD}=0.0067\end{array}$ \\
\hline SSD $=2.0 \%$ & $\mathrm{RSD}=0.6 \%$ & $\mathrm{RSD}=1.3 \%$ \\
\hline Stated content & 0.800 & 0.625 & 0.500 \\
\hline
\end{tabular}

$\overline{\mathrm{X}}$ - mean value, SD - standard deviation, RSD - relative standard deviation.

basis for using the developed procedure in the quantitative analysis. It can therefore be assumed that the method is specific for analyte components, which allows obtaining reliable results (Fig. 3).

The developed method has been fully validated in accordance with the guidelines of the International Conference on Harmonization. In the validation process, linearity, accuracy, precision, the limit of detection LOD, and limit of quantification LOQ were determined. The method is characterized by a high sensitivity; LOD was $0.056 \mathrm{mg} / \mathrm{spot}$ for CAN, $0.043 \mathrm{mg} / \mathrm{spot}$ for HCT and $0.049 \mathrm{mg} / \mathrm{spot}$ for ROS; LOQ was: $0.169 \mathrm{mg} / \mathrm{spot}, 0.130 \mathrm{mg} / \mathrm{spot}$ and $0.150 \mathrm{mg} / \mathrm{spot}$, respectively. Recovery of the determined components was in the range from $96.80 \%$ to $101.75 \%$. The results of the determination of individual components are characterized by high precision, RSD was in a narrow range from $0.43 \%$ to $2.12 \%$. The determined validation parameters are presented in Table 1.

The linearity of the method was checked in a wide concentration range: from 0.048 to 1.824 $\mathrm{mg} / \mathrm{spot}$ for CAN, from 0.058 to $1.102 \mathrm{mg} / \mathrm{spot}$ for HCT and from 0.032 to $1.216 \mathrm{mg} /$ spot for ROS.

The efficiency of the estimation of calibration models was checked by conducting appropriate statistical tests. Based on Mandel's test results ( $\mathrm{p}<$ 0.05 for all tested substances) a quadratic fit was selected. The normal distribution of residuals was confirmed in all cases by the Shapiro-Wilk test. The Durbin-Watson test results indicate no significant autocorrelation of random components only in the case of ROS. The Lagrange test was performed for HCT and CAN, which showed no significant autocorrelation. The Bartlett test confirmed the homogeneity of the variance of random components in the proposed models $(p>0.05)$. The results of statistical tests and equations are presented in Table 2.

The proposed method was successfully used for the analysis of Carzap ${ }^{\circledR} \mathrm{HCT}$ and Suvardio tablet extract solution - model mixture (Table 3 ). The chromatograms obtained during the analysis, on which no additional peaks from the auxiliary components of the tested drug form were observed and recovery values indicate that the excipients have no effect on the determination results. This allows us to state that with minimal effort and the elimination of complicated activities related to the appropriate sample preparation, results with a satisfactory level of precision and accuracy have been achieved.

\section{CONCLUSIONS}

This study presents a new method for the simultaneous determination of candesartan, hydrochlorothiazide, and rosuvastatin in a model mixture of a potential ternary pharmaceutical preparation using TLC - densitometric method. The developed procedure has been validated in accordance with the ICH requirements for chromatographic methods. The TLC method is fast and requires no complicated pre-treatment or tedious extraction procedure, and the obtained results are characterized by high accuracy and precision. The choice of the components of the model mixture was not accidental because in hypertension polytherapy you can find more and more often research on the effectiveness of using various combinations of substances from the group of angiotensin II receptor blockers, diuretics, and HMG-CoA reductase blockers. Due to such a direction in therapy, the pharmaceutical industry is introducing new complex preparations to the market, which in clinical trials gave satisfactory results and underwent the registration procedure. However, the goal of analysts is to develop new, simple, cheap, and easily available methods that could be used for routine analysis of tested drugs in quality control laboratories.

\section{Conflicts of interest}

The authors have declared no conflicts of interest. 


\section{REFERENCES}

1. http://www.clinicaltrials.gov/ show/ NCT0046 8923 (accessed on 3. 10. 2019).

2. Moisei A., Totan M., Gligor F.G., Craciun I., Todoran N., et al.: Farmacia 64, 612 (2016).

3. Balamuralikrishna K., Syamasundar B.: Pharma. Chem. 2, 231 (2010).

4. Harikrishnan N., Vijaya Vara Prasad M., Mohamied A.S., Prabahar K.K.: Int. J. Pharm. Sci. Res. 7, 75 (2016).

5. Erk N.: J. Liq. Chromatogr. Related Technol. 26, 2581 (2003).

6. Youssef R.M., Maher H.M., Hassan E.M., ElKimary E.I., Barary M.A.: Int. J. Appl. Chem. 6, 233 (2010).

7. Stolarczyk M., Maślanka A., Krzek J.: J. Liq. Chromatogr. Related Technol. 31, 1892 (2008).

8. Mehta B.H., Morge S.B.: J. Planar. Chromatogr. Mod. TLC 21, 173 (2008).

9. Kull M.E.A., Naguib I.A.: Curr. Pharm. Anal. 13, 188 (2017).

10. Routhu K.C., Annapurna M.M.: IJPT. 8, 17528 (2016).

11. Erk N.: Pharmazie 58, 796 (2003).

12. Belal T.S., Daabees H.G., Abdel-Khalek M.M., Mahrous M.S., Khamis M.M.: J. Pharm. Anal 3, 118 (2013).

13. Ali H., Zafar F., Shah S.N., Mallick N., Naveed S., et al.: Lat. Am. J. Pharm. 35, 1710 (2016).

14. Chen D., Lin Z., Wang Q., Su K., Mo J., et al.: Lat. Am. J. Pharm. 35, 2314 (2016).

15. Swathi S., Kumar H.T., Rao P.K., Rao S.Y.: Int.
J. Pharm. Pharm. Sci. 7, 209 (2015).

16. Purkar A.J., Balap A.R., Sathiyanarayanan L., Mahadik K.R.: Int. J. Pharm. Pharm. Sci. 6, 704 (2014)

17. Ramadan A.A., Al-Akra H., Maktabi M.: Int. J. Pharm. Pharm. Sci. 6, 180 (2014).

18. Ramadan A.A., Mandil H., Alshelhawi N.: Int. J. Pharm. Pharm. Sci. 6, 579 (2014).

19. Gupta A., Mishra P., Shah K.: E- J. Chem. 6, 89 (2009).

20. Ramadan A.A., Mandil H., Ghazal N.: Int. J. Pharm. Pharm. Sci. 7, 389 (2015).

21. Ramadan A.A., Mandil H., Ghazal N.: Int. J. Pharm. Pharm. Sci. 7, 300 (2015).

22. Silva T.A., Zanin H., Vicentini F.C., Corat E.J., Fatibello-Filho O.: Sensor. Acutat. B-Chem. 218, 51 (2015).

23. Silva T.A., Pereira G.F., Fatibello-Filho O., Eguiluz K.I.B., Salazar-Banda G.R.: Diam. Relat. Mater. 58, 103 (2015).

24. Karadas-Bakirhan N., Gumustas M., Uslu B., Ozkan S.A.: Ionics 22, 277 (2016).

25. Yusuf S., Phil D., Lonn E., Pais P., Bosch J., et. al.: N. Engl. J. Med. 374, 2032 (2016).

26. Park D.B., Jang K., Lee J.W., Park C.W., Lee B.H., et. al.: Int. J. Clin. Pharmacol. Ther. 55, 286 (2017).

27. http://www.ich.org/fileadmin/Public_Web_ Site/ICH_Products/Guidelines/Quality/Q2_R1/ Step4/Q2_R1_Guideline.pdf; (accessed on 20. 10. 2019).

28. Polish Pharmacopoeia, $\mathrm{XI}^{\text {th }}$ edition, The Office for Registration of Medicinal Products, Medical Devices and Biocidal Products, Warszawa 2018.

(C) 2020 by Polish Pharmaceutical Society. This is an access article under the CC BY NC license (http://creativecommons.org/licenses/by-nc/4.0/). 